\title{
DETERMINANTS OF THE EFFICIENT TRANSPORTATION CONNECTIVITY BETWEEN THAILAND AND YUNNAN ALONG NORTH-SOUTH ECONOMIC CORRIDOR OF GMS
}

Yuanchun Xia a , BoonsubPanichakarn ${ }^{\mathrm{b}}$, SahasBunditkul c

ab Naresuan University, Phitsanulok, Thailand

c Asian Institute of Technology, Bangkok, Thailand

Corresponding email: 303492135@qq.com

\begin{abstract}
This paper aims to, from the new approach of the efficient transportation connectivity (ETC), find solutions to blocks in the transportation between Thailand and Yunnan (PRC) along North-South Economic Corridor (NSEC) of GMS. After the introduction, a literature review with the key term connectivity is presented. The following section 3 discusses methodologies from both quantitative approaches and qualitative perspectives, the former of which is designed for an assessment of logistics performance along NSEC and a cargo volume's predication in the year of 2016-2015, and the latter of which is to make the complementary. Results of the methodologies are presented afterwards. Then, findings are shown in section 4 to provide reasons for and solutions to the constraints in the logistics performance. The last section indicates how to define and understand ETC, as well as the determinants of ETC along NSEC of GMS. Also, limitations are to be discussed therein, with the recommendation for further study on this topic.
\end{abstract}

Keywords: Efficient Transportation Connectivity (ETC), North South Economic Corridor (NSEC), Logistics Performance, Forecasting, Solutions \& Determinants

\section{Introduction and Purpose}

As a flagship cross-national program of GMS, the North-South Economic Corridor (NSEC) plays significantly role for Thailand, Yunnan, PRC and People's Democratic Republic of Lao(Lao PDR) especially after its completion in 2013. Thailand requires the greater connectivity with regional economies to progress its economy for open and domestic concern. Shocked by the Asian financial crisis(1997-1998), the global financial (2008-2009)and floods in 2011 and frustrated by heavy public deficit (approximately 43.5\% of GDP in 2012), Thailand requires a new path to a greater market such as PRC and India to support its domestic economic structure pattern's change, increasing outward FDI in labor-intensive and resource-intensive sectors. And for Yunnan Province, a landlocked province, NSEC has opened the land route to major external markets in Southeast Asia or Association of South-East Asian Nations (ASEAN), and an access to the Andaman Sea and South China Sea via intersects of the East-West Economic Corridor (EWEC) in Thailand's Tak and Phitsanulok provinces. Thus, the NSEC is the connection, entailing the strategically economic and political significance, for People's Republic of China (PRC) via Yunnan province. İn 


\section{Asia Pacific Journal of Advanced Business and Social Studies \\ ISBN (eBook): 9780994365675 I ISSN : 2205-6033 \\ Year: 2017 , Volume: 3, Issue: 2}

addition, Lao PDR, more than most countries, suffers the constraints of physical location in shaping its foreign policy. However, by moving resolutely and responding to Thai and Chinese gestures, Lao PDR has broadened its range of donors, trading partners, and investors. Further, via the connection with Thailand in Laem Chambang Port, Lao PDR could be linked to the sea access for more opportunitiesin foreign exchange. However, due to the existing challenges along NSEC, the positive effects, however, from both micro and macro perspectives, have gone far away from what has been expected after time and cost-consuming investment of physical infrastructure, and detrimental effects of road development on environment and climate changes evolve to be burgeoning issues unexpected. As such, based on the current physical infrastructure of NSEC, which is now a lesser constraint, how to make the corridor seamless or efficient in transportation connectivity, hard and soft, is the core consideration for each economy.

This study is based on the three principal general notions. Any corridor would not work efficiently with only the completion of the physical infrastructure, which is particularly the case in the cross-national projects, where governmental convention is a necessary in implementation. In addition, the study of this corridor is based on the general concept of making full use of the current or existing passage of NSEC, rather than complementing new access or investment into the corridor. Further, solutions to the current physical connectivity should take the trend of cargo and passengers' volume at present and at future 5 or 10 years into account. So, from the chronological aspects, the possible volume in the next 5 years or one or two decades could influence the regulations, cooperative strategies among members along this corridor and countermeasures for the obstacles quo. For this concern, some questions could be categorized to be studied: what the status quo of logistics performance along NSEC is; what the cargo volume would be in next 10 years; what the main obstacles and solutions are; what key determinants of efficient transportation connectivity are and which key determinants are essentially critical for NSEC in particular.

The rest part of this paper is to be organized as below. Part two is the literature review related with logistics performance and connectivity along NSEC. The followed part is the data of logistics performance in time-cost model, cargo predication for this corridor in 2016-2025 and interview, based on which, findings about reasons for the inefficient transportation connectivity are discussed. Conclusion about what is efficient transportation connectivity (ETC) and its determinants in the Part five is to be presented. Also, the limitation of this research and recommendations are also given for further study.

\section{Literature Review}

Taking the connectivity as the key term, this part aims to review researches concerning international logistics performance between the Thailand and Yunnan Province of China.

One of the researches worthy of being mentioned has been contributed by Ruth Banomyong (2008) since this is the only published paper studying the logistics performance along NSEC. Taking the Kunming-Bangkok as one branch of the NSEC, the author describes that infrastructure connectivity is almost complete, but border crossings are still the weakest link 


\section{Asia Pacific Journal of Advanced Business and Social Studies \\ ISBN (eBook): 9780994365675 I ISSN : 2205-6033 \\ Year: 2017 , Volume: 3, Issue: 2}

in the macro-logistics system. The pure transport cost on all three routes is less than the border crossing and transit charges. So how to transform the NSEC sub-corridors from a transport corridor into fully fledged economic sub-corridors remains as the key challenge.

ADB and ADBI (2009) studied the overall gains from Pan-Asia connectivity through increased market access, reduced trade costs, and more efficient energy production, approximately producing large real income gains of around $\$ 13$ trillion for developing Asia during 2010-2020 and beyond. A lot of gain could be benefitted by reducing trade cost, improving the integration, helping reduce the poverty and create a single market.

M. Rahmatullah, (2009) studies the possible benefits that Bangladesh and the other neighboring countries (Nepal, Bhutan and North East India) could derive from the regional transport connectivity in South Asian Association for Regional Cooperation (SAARC). Impact of poor regional connectivity and the need for regional connectivity in road and rail are presented. For the sake of establishing effective regional transport connectivity among the countries of North Eastern sub-region of SAARC, the following initiatives are proposed, namely, mobilization of political supports, cooperation and facilitation of borders' operation with on-line IT connectivity.

$\mathrm{ADB}$ and Asian Development Bank Institute(ADBI, 2013) defines "connectivity" and its scope and sets out issues in relation to improve connectivity between South and Southeast Asia for greater economic integration. They point out that connectivity is the key for economies' sustainable economic progress in this region since the global financial crisis in recent years. Particular concern is taken for Myanmar, an effective bridge, who can be gained substantially from the connectivity and however, remains key physical barriers or hindrances to cross-subregional trade and efficient and effective connectivity between seaports and railway and road networks. In addition, major land infrastructure gaps have been identified in links between India and Myanmar, Bangladesh and Myanmar, and Myanmar and Thailand. Thus, they suggest that an integrated approach to connectivity is needed to move forward.

Luisa Alama'-Sabater, Laura Ma'rquez-Ramos and CelestinoSua'rez-Burguet (2013) indicate that transport connectivity is one of the key actions in European Union (EU) for a single market. With the Mediterranean Corridor as the target, one of the priority projects at European level, they certify that interregional trade among Spanish regions benefits from its neighbours' transport networks by using aspatial approach. Also, they consider the efficiency and effectivenessof the transport network could be progressed by connectivity in a broad sense related to the services and cooperation of transport operators.

ADBI, (2014) shows that infrastructure connectivity in the central Asia should be efficiently used to ensure the transition tomarket-oriented economies due to lack of autarky. And the growth can be expected from the sequencing trade and investment connectivity with rest of the world, especially further eastward to Asia and westward to Europe, thus causing the regional connectivity to be a high priority.

Ajitava Raychaudhuri\& Prabir De (2014), using the partial equilibrium model, suggest that 


\section{Asia Pacific Journal of Advanced Business and Social Studies \\ ISBN (eBook): 9780994365675 I ISSN : 2205-6033 \\ Year: 2017, Volume: 3, Issue: 2}

much of the potential of the rise in exports among the South Asia Subregional Economic

Cooperation(SASEC) countries is restricted by the stringent sensitive lists under The South Asian Free Trade Area(SAFTA). And interviews in their research argue that the conditions at both sea and land ports are far from satisfactory in Bangladesh. Also, economic corridors would help the countries better integrate globally.

Chiranjib Neogi (2014) studies the effect of economic corridors on the development of countries through trade, and their impact on industrial agglomeration in border-sharing countries. The basic result are borders with developed infrastructures on either side facilitate trade between two countries and agglomeration of industriesin India, among many other things, depends on improved infrastructural facilities such as economic corridors in the border region and human capital.

Hector \&Corpuz (2014) from ADBI examine the road and railway links in Myanmar connecting northeast India on the one side with the rest of Southeast Asia on the other. Priorities of connectivity are put on the projects between Myanmar and northeast India, constructing deep-sea ports and on strengthening north-south connectivity via roads, railways, and inland waterways. In addition, the land route in Myanmar connecting to India is extended to Yunnan, which could provide connectivity between markets in India, Myanmar, and the PRC. It could also provide opportunities for Myanmar to earn transit fees. Therefore, they suggest that Myanmar must take an analysis of costs and benefits and put regional connectivity as part of a reform agenda and pay attention to soft infrastructure to improve policies and institutional arrangements within and among the countries concerned.

Kunal Sen (2014) deems that logistics and physical connectivity have become important determinants of trade flows in parts and components of South Asian countries. He indicates that a regional corridor requires outer nodes and transport connectivity as well as small nodes surrounding the corridor. He suggests that countries in South Asia could take both national and regional corridors as catalysts to integrate with East and Southeast Asia, an access to global production networks. In addition, such measures could be taken in terms of the easing of logistics constrains along corridors, working with government policy that can identify impending constraints and coordinate the complex institutional challenges that originate when economic corridors traverse different regions.

Moe Thuzar, Rahul Mishra, Francis Hutchinson, Tin MaungMaung Than, and Termsak Chalermpalanupap from ADBI (2014) study cross-border connectivity between South and Southeast Asia, in which India, Myanmar, and Thailand provide the basis for implementing multi-modal connectivity projects, for building upon and improving existing infrastructure and processes for cross-border connectivity in trade. They suggest to accelerate some pending connectivity projects with align the domestic program with regional projects as well as dovetailing hard and soft connectivity. Special attention also is given to support Myanmar in border areas. 
Prabir De (2014) analyzes the linkages between economic corridorsand regional integration and indicates that good governance help achieve the full economic potential, for which, more effective policy approaches towards improved governance are needed to facilitate the development of regional infrastructure and to complement regional infrastructure development initiativesin South Asia.

Chirathivat\& Cheewatra koolpong (2015) review the current promotions of connectivity of Thailand between core-periphery and between Thailand and neighboring countries, including NSEC of GMS for better preparation of ASEAN Economic Community (AEC). They indicate that improving connectivity, inside Thailand, within ASEAN, and between South Asia and mainland Southeast Asia, could become the key for Thailand's future development. So suggestions are proposed in ASEAN-India cooperation framework in institutional connectivity to harmonize the legal and regulatory frameworks.

The conclusion of the reviews could be summarized as below. Firstly, for individual nations, Myanmar and India are the two focused due to their unique geographic locations in the connectivity's network or production network. While at the regional level, central Asia and South-EastAsia receives attention than South Asia and other sub-region such as GMS. Secondly, such important researches have experienced a transition of focus from the physical transport infrastructure to the software initiatives, although in some individual countries such as in Bangladesh and Myanmar, improvement of hardware infrastructure or filling some missing links remain as the priority project of transport connectivity. Thirdly, some solutions to overcome the current constraints in software have been proposed in a general or macro way, such as governmental policies' reform and cooperation. Such countermeasures are certified to be necessary, the individual participants (consignors, consignees, brokers, forwarders, etc.) in transport, however, are sparsely and slightly mentioned. Also, effective and/or efficient transport have been described occasionally for the purpose in a regional logistics or production network, but, what an efficient transport connectivity is and how to get to access remain suspended. Fourthly, economic corridors are studies from the theoretical nature. Likely, measures are for policy makers in general concern.

Thus, the implication of the literature review can be in many perspectives. Each economy should be studied and included in this connectivity network in Asia, from individual nations' standpoint and sub-regional (like GMS) and regional levels, among who are independently in sovereignty and dependently in connectivity in borders. For a better connectivity, how to integrate the national infrastructure into the sub-regional or regional one is worthy of a systematical and precise study. In addition, connectivity in software needs feasible solutions to the constraints, not a general guide instead, with all participants included, in individual countries or economies, sub-regions and regions. Further, from the far-sighted concern, efficient transport connectivity should be exploited with one sub-region as the pioneer, the base for or the first step to the whole Asia's seamless connectivity. 


\section{Methodology}

Based on the result in the review, this part aims to demonstrate how the connectivity along NSEC through the cost-time model (1992-2016) and the Fuzzy Linear Regression for potentials (2016-2025), the base for the possible constraints of an efficient transportation connectivity and countermeasures.

\subsection{Cost-Time Methodology}

In order to work out solutions to constrain or challenges through analysis of logistics performance along NSEC, we adopt cost/time methodology, a tool to analyze bottlenecks, to describe the current logistics situation, to illustrate the cost and time components by available routes and modes as well as to illustrate the delays at borders or other inspection points up to the point of destination within a transit transport corridor. So, two individual graphs-time over distance and cost over distanceare to be expected. The time-distance and cost-distance graphs are to be illustrated in below two graphs.

As the graph 1 shows, there are two sudden jumps, where are the two border-crossing points of Boten and Huaxay. In particular, the time at Boten (Yunnan,PRC to Lao PDR) costs more than that of in Huaxay (Lao PDR to Thailand). Except the two points, the time develops evenly as the distance adds. In addition, transport of one kilometer in average in general requires about 0.02 hour, in Yunnan about 0.02 , in Thailand about 0.17 , while the data in Lao part is about 0.04, two times than the one in general average and more than two times than those of in Thailand and Yunnan. From another way, time in two points constitutes about 23\% in total, while the distance in this part only occupies about $13 \%$.

As the graph 2 indicates, the line develops smoothly with the unchanged slope in general, with two points of Boten and Huaxay as the exception, where the average cost is about RMB 0.58/metric ton/kilometer. The two points though, do not fluctuate as big as those in Graph 1 . And the cost in Yunnan is about RBM 0.53/ton/kilometer, in Thailand about RMB $0.22 /$ ton/kilometer, the least part in general, and the total average along this corridor about $\mathrm{RMB} 0.38 /$ ton/kilometer. Likewise, 20\% cost is taken by operations in two border-crossing points, while the distance in this part only occupies about $13 \%$. 


\section{Graph 1: Graph Time-Distance}

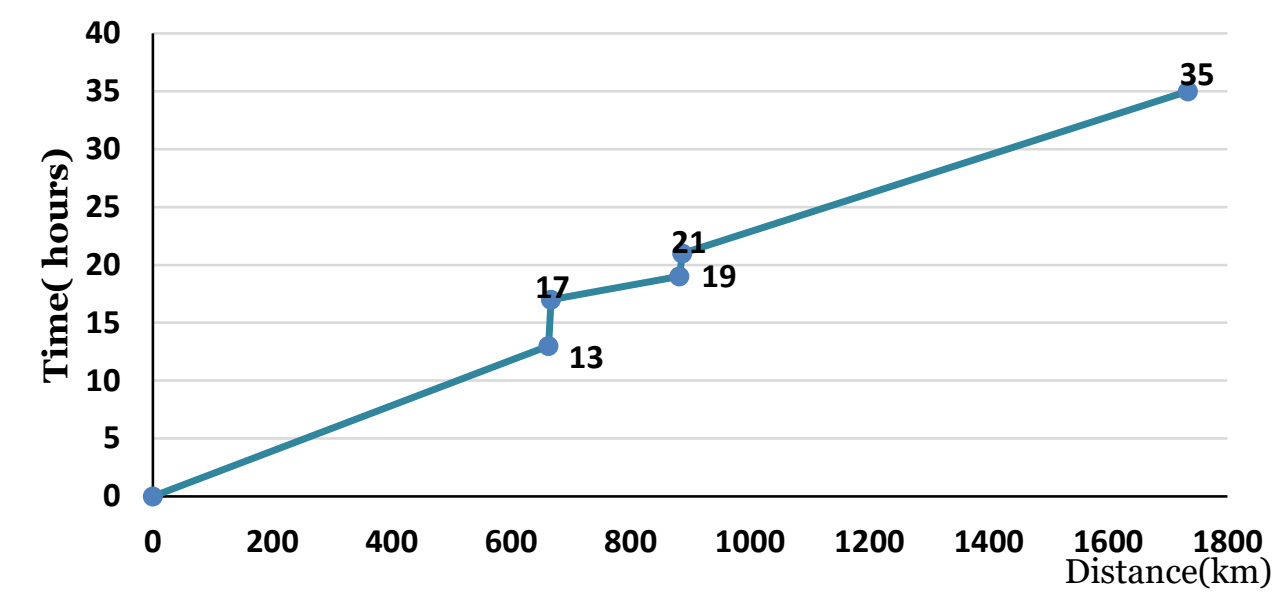

Source: Aothers' calculation.

Graph 2: Graph Cost-Distance

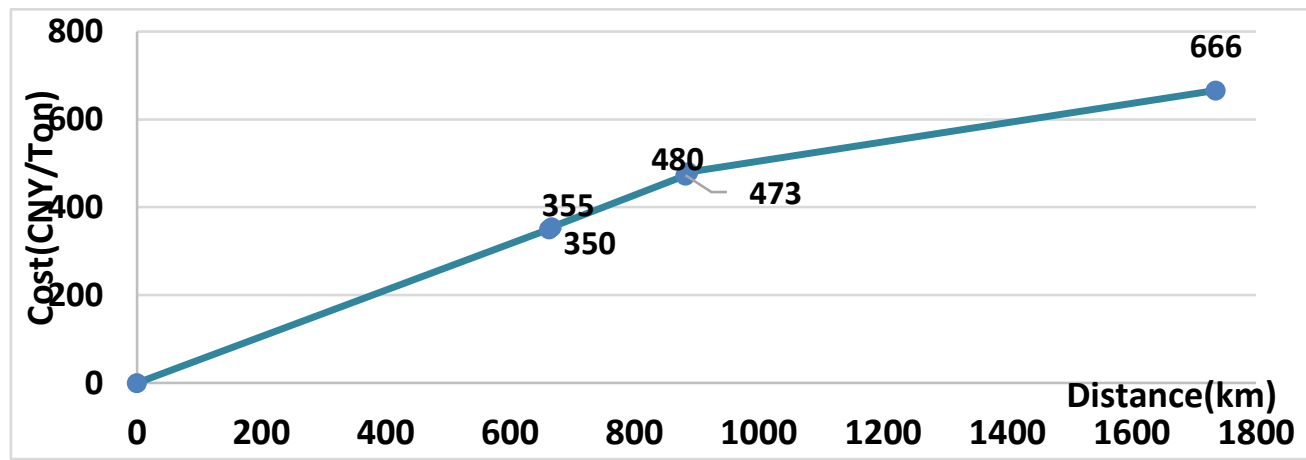

Source: the aother's calculation.

Similarly, as it is reported by the World Bank the LPI (Logistics Performance Index) in GMS, compared with the performance in Singapore, there is not big progress since 2007 to 2016.

Table 1: World Bank Doing Business Indicators (Rank and trading across borders)

2016

\begin{tabular}{|c|c|c|c|c|c|c|c|c|c|c|c|c|c|c|}
\hline \multirow{2}{*}{$\begin{array}{c}\text { Co } \\
\text { unt } \\
\text { ry }\end{array}$} & \multirow{2}{*}{$\begin{array}{c}\text { Ov } \\
\text { era } \\
\text { ll } \\
\text { Ra } \\
\text { nk }\end{array}$} & \multirow{2}{*}{$\begin{array}{c}\mathrm{Tr} \\
\mathrm{ad} \\
\mathrm{e} \\
\mathrm{B} \\
\mathrm{C} \\
\mathrm{P} \\
\mathrm{Ra} \\
\mathrm{nk}\end{array}$} & \multicolumn{3}{|c|}{$\begin{array}{l}\text { Time to } \\
\text { Export }\end{array}$} & \multicolumn{3}{|c|}{ Cost to Export } & \multicolumn{3}{|c|}{$\begin{array}{l}\text { Time to } \\
\text { Import }\end{array}$} & \multicolumn{3}{|c|}{$\begin{array}{l}\text { Cost to } \\
\text { Import }\end{array}$} \\
\hline & & & $\begin{array}{c}\text { Docu } \\
\text { ment } \\
\text { s }\end{array}$ & $\begin{array}{l}\mathrm{B} \\
\mathrm{C} \\
\mathrm{P}\end{array}$ & $\begin{array}{l}\text { Tra } \\
\text { nsp } \\
\text { ort }\end{array}$ & $\begin{array}{c}\text { Docu } \\
\text { ment } \\
\text { s }\end{array}$ & $\begin{array}{l}\mathrm{B} \\
\mathrm{C} \\
\mathrm{P}\end{array}$ & $\begin{array}{l}\text { Tra } \\
\text { nsp } \\
\text { ort }\end{array}$ & $\begin{array}{c}\text { Docu } \\
\text { ment } \\
\text { s }\end{array}$ & $\begin{array}{l}\mathrm{B} \\
\mathrm{C} \\
\mathrm{P}\end{array}$ & $\begin{array}{l}\text { Tra } \\
\text { nsp } \\
\text { ort }\end{array}$ & $\begin{array}{c}\text { Docu } \\
\text { ment } \\
\text { S }\end{array}$ & B & $\begin{array}{l}\text { Tra } \\
\text { nsp } \\
\text { ort }\end{array}$ \\
\hline $\begin{array}{l}\text { Chi } \\
\text { na }\end{array}$ & 84 & 96 & 21 & $\begin{array}{l}2 \\
6\end{array}$ & 7 & 85 & $\begin{array}{l}5 \\
2 \\
2 \\
\end{array}$ & 306 & 66 & $\begin{array}{l}9 \\
2\end{array}$ & 7 & 171 & $\begin{array}{l}7 \\
7 \\
\end{array}$ & 320 \\
\hline
\end{tabular}




\begin{tabular}{|c|c|c|c|c|c|c|c|c|c|c|c|c|c|c|}
\hline $\begin{array}{c}\text { Lao } \\
\text { PD } \\
\text { R }\end{array}$ & $\begin{array}{c}13 \\
4\end{array}$ & $\begin{array}{c}10 \\
8\end{array}$ & 216 & 3 & 2 & 235 & 7 & 150 & 216 & 5 & 2 & 115 & 3 & 200 \\
6 & & & & & & & & & & & \\
7 & & & & & & & & & & & & & & \\
\hline $\begin{array}{c}\text { Thai } \\
\text { land }\end{array}$ & 49 & 56 & 11 & 5 & 2 & 97 & 2 & 147 & 4 & 5 & 2 & 43 & 2 & 147 \\
1 & & & & & & & & \\
\hline
\end{tabular}

Notes: Ranking among 189 countries; time and cost calculated on a 15 tonnes trucking from warehouse to the nearest ports; "documents" are all the paper work required for exports and imports; BCP is border crossing post.

Source: World Bank Doing Business Indicators 2016

\subsection{Fuzzy Linear Regression (FLR)}

Since the freight volume of road has close relations with the local economy,so the forecasting of freight volume along NSEC must take determinants or influencing factors into care consideration. This paper takes the Grey Correlation to calculate the correlation of freight volume with each parameter. The result is shown in Table 1.

Table 2: Correlation Degree

\begin{tabular}{|l|l|l|l|l|l|l|l|}
\hline & \multicolumn{4}{|l|}{ Thailand } & \multicolumn{2}{l|}{ Yunnan } & Yunnan-Thailand \\
\hline Parameters & GDP & Freight & POP & GDP & Freight & POP & Trade \\
\hline Correlation & 0.66 & 1.57 & 0.68 & 0.70 & 0.61 & 0.65 & 0.70 \\
\hline
\end{tabular}

Source: Authors' Calculation.

The FLR model is needed to evolve to the forecasting model for road freight volume. The relation between the road freight volume $y$ and the social indicators is supposed as below

$$
\mathrm{y}=\mathrm{A}_{1} \mathrm{x}_{1}+\mathrm{A}_{2} \mathrm{x}_{2}+\mathrm{A}_{3} \mathrm{x}_{3}+\mathrm{A}_{4} \mathrm{x}_{4}+\mathrm{A}_{5} \mathrm{x}_{5}+\mathrm{A}_{6} \mathrm{x}_{6}+\mathrm{A}_{7} \mathrm{x}_{7}
$$

In this equation, $\mathrm{x}_{1}, \mathrm{x}_{2}, \mathrm{x}_{3}, \mathrm{x}_{4}, \mathrm{x}_{5} \mathrm{x}_{6}$ and $\mathrm{x}_{7}$ represent GDP in Thailand and Yunnan, POP in Thailand and Yunnan, road freight tonnage in Thailand and Yunnan and trade value between Thailand and Yunnan respectively. And $A_{1}$ to $A_{7}$ are the coefficients of counterpart of $x_{1}$ tox accordingly.

According to the Table 1, we can select those with more than $70 \%$ of correlation to set up the model as

$$
\mathrm{y}=\mathrm{A}_{2} \mathrm{x}_{2}+\mathrm{A}_{4} \mathrm{x}_{4}+\mathrm{A}_{7} \mathrm{x}_{7}(2)
$$

Then, we take the previous data in year 2006 to 2015 into the model $(\mathrm{H}=0.8)$. With the EXCEL software, the fuzzy coefficients are concluded to be (0.000,0.00o), (3168.869,0.000) and $(58570.933,84602.620)$ respectively. Thus we can conclude the predictive model asy=

The result is shown below, for the freight prediction, the fuzzy liner regression performs well 


\section{Asia Pacific Journal of Advanced Business and Social Studies \\ ISBN (eBook): 9780994365675 । ISSN : 2205-6033 \\ Year: 2017, Volume: 3, Issue: 2}

with the deviation within 30 percent, based on data in 2006 to 2015. Considering the financial crisis in 2008, authors remove the data in 2007 and 2008 for a general testing and adjusting of the model. The total analogue value since 2006 to 2025 shows a gradually climbing up tendency, representing the slope into a liner manner. And the volume in 2025 would be about 1.26 times than the value in 2015 and 12.98 times than it in 2006.

Graph 3: Forecasting Result-Line Graph (2016-2025)

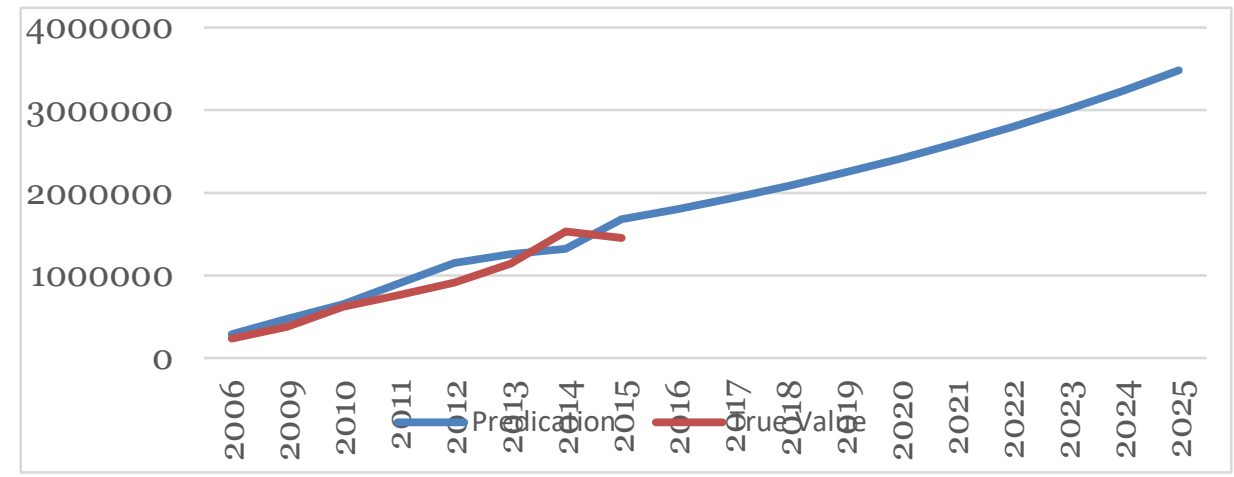

Notes: Volume means cargo volume via Mohan Border Crossing (tones)

Source: (Xia, et al., 2015, pp. 121-134)

\subsection{Interview}

As shown in time-cost model, this methodology could only illustrate the cost and time components of movement from origin to destination by each available route and mode as well as illustrating the delays at borders or other inspection points up to the destination within the corridor. Thus qualitative approaches are needed to cover the responsiveness, reliability, and security for a comprehensive understanding the logistics performance along NSEC. For this purpose, interviews are to be conducted for information complementary to the quantitative analysis. There are two parts in the interview, one is for the logistics performance and another is for potentials along this corridor. In the part one, focus are put on reasons why the less efficiency occurs at customs clearance directly related its process such as required charges under-table, documents complexity and working efficiency and proficiency and the easiness of cargo handling and other indirectly associated adverse factors like the timeliness, the security, facilities and barriers in languages and standards. Also, how to improve the connectivity are to be expected from interviewees. And part II is designed for the prospects of NSEC. What are the positive influencing factors and how to exploit the potential are to be set accordingly.

The interviewees are selected from both theory and practice concern, with the latter as the focus. Thus professionals, including 10 academic associate professors or professors, 15 logistics companies along this route, 2 research associations in Yunnan province and 3 experts from $\mathrm{ADB}$, are interviewed via calling or face-to-face meeting. 10 professors are all professionals in international logistics, including 6 associated professors and 4 professors, in 


\section{Asia Pacific Journal of Advanced Business and Social Studies \\ ISBN (eBook): 9780994365675 I ISSN : 2205-6033 \\ Year: 2017 , Volume: 3, Issue: 2}

which 6 associate professors1 are from Yunnan province and Guangdong Province, China, and the rest four professors from Thailand. Furthermore, the 15 logistics enterprises are chosen from both China and Thailand, who have operated directly and indirectly the cross-border transportation along this corridor. The two associations are GMS logistics center, Kunming and The Chartered Institute of Logistics, Yunnan, both who are top logistics associations in Yunnan province.

All interviewees evaluate the general logistics performance of NSEC as far from efficiency and agree the less efficiency occurs in the section of Lao PDR, with one exception. On the one hand, in terms of the un-satisfaction in customs clearance, among negative factors, the software infrastructure is really what encumber the customs clearance. Regarding the whole cost for transportation, what makes all participants think un-reasonable is not cost in transport itself, but in the charges at border crossing for transshipment and customs clearance instead. And for the whole logistics performance, no sound management and lack of the unified logistics standards are being complained by majority of interviewees from the practical perspective. On the other hand, for exploiting the potentials along this corridor, due to the good relationship between Thailand and China in a comprehensive way, the origin of the transportation, the trade complementary and competitiveness is the least concern for interviewees. Thus, they are optimistic about the future of this corridor and cares more about transparency and efficiency of customs, stability of international financial, political and economic situations and road conditions. In addition, solutions are in various aspects, all which may receive different concern with no distinguish diversities though. However, focus of solutions are put on the CBTA implementation with simplifying the customs procedures included at border crossing points, where governmental cooperation and coordination requires, competent logistics association in practice, IT infrastructure and E-commerce for incentive of further trade possibility.

\section{Constrains to ETC}

One of the general findings is the logistics performance along NSEC is far from efficient, especially at the part of border crossing points at Lao PDR. So, what makes this corridor far from efficiency and hard to further to be tapped constitute as the key focus and priority at this moment. About the potentials of NSEC, the freight volume represents a general steady increasing trend except two years 2007 and 2008, when the financial crisis erupted. Such data certifies that the construction of physical infrastructure is only a pre-condition, rather than a guarantee, to attract trade between Thailand and Yunnan. And the predication shows, if solutions could be found and implemented effectively, NSEC would attract more freight volume than predicted, namely, the trade between Thailand and Yunnan would grow up with higher rate. 


\subsection{Implementation of CBTA}

The GMS Cross Border Transport Agreement (CBTA) has been designed as a general transport facilitation agreement required by a basic requirement of transiting of goods over boundary of a foreign economy, which could cover all aspects of border crossing for goods and passengers and be agreed by all participants (ADBI, 2014). Starting at the trilateral transport agreement between Thailand, Lao PDR and Vietnam signed in 1999, CBTA could claim to have been fully ratified, including Annexes and Protocols, by all GMS member states in November 2015. Except the time-consuming proceedings in ratification by parts and then by all members, the implementation practice thereafter, however, is exposing the CBTA to be weak support to cross border transportation and trade. For one thing, despite the implementation of a few CBTA articles, trade movements continued to be regulated through existing bilateral agreements. For another, practical difficulties and inconsistency occurred in different technical standard specifications of vehicles, temporary import permit supported by security guarantees from carriers and trailers (when applied), the issuance of temporary permits, the need to get proper transit guarantees in foreign territory and empty back-haul as well.

Further, a serious problem relies on the practicality of the transit guarantee for goods. The non-transferability of the guarantee from one Customs to another and the need to replenish the guarantee impose a serious financial burden on the guarantor (ADB, 2016). What's more, the "Customs Transit System" (CTS), the key component of CBTA, is still being suspended. In addition, the CBTA, as a multilateral agreement, nevertheless, is a guideline which is not binding legal commitments. Under such circumstances, members of GMS tend to rely on bilateral agreements, old ones or even signing new ones, without complying with the "simplification of customs procedures" or the Perishable Goods Annex and the treatment of transportation of live animals. As an instance, the inspection procedures are divided into the inspection of people and goods. The procedure related to person checking can be accelerated, but the goods inspection process should be carried out at an equivalent speed for the proportionate benefits of both economies' domestic logistics providers.

\subsection{Border Crossing Operation}

As indicated through time and cost over distance graphs, the biggest and first challenge of efficient transportation along NSEC relies on the part at border crossing. Customs laws in Lao PDR and Myanmar require that all goods must be cleared at entry points, the causes of general congestion. The problem is aggravated by the practice of restrictive "hours of opening" of Customs offices at border crossing points, being generally from 8 am to 5 pm, 5 days a week and with lunch breaks. Further, the absence of customs, the price distortion as a result of unofficial payments of corruption, complex documents required ${ }^{2}$ also lead to the current high logistics cost. 


\section{Asia Pacific Journal of Advanced Business and Social Studies \\ ISBN (eBook): 9780994365675 I ISSN : 2205-6033 \\ Year: 2017 , Volume: 3, Issue: 2}

Transshipment of cargo is another main detriment in Huayxay, Boten, and Mohan. Boten, where the facilities have not improved much so that transshipment is still done using manual labor, opposed to container swaps, is the most important transshipment point since Thai and PRC trucks can both enter Lao PDR. Thai-PRC trade is mainly transferred in Boten and Huayxay whereas Lao-PRC trade is mainly transferred in Mohan. The manual transshipment process poses a significant risk for cargo damages. This is particularly detrimental for transportation of fruits and vegetables, the main exchange of trade goods between Thailand and Yunnan, in transshipment, which is taken place in an open, unhygienic environment due to lack of cold chain facilities.

Therefore, due to the complicated operations in border crossing points, irrational time and cost over distance at borders comes from, in the artificial and practical layer, transshipment as the core, requirements to obtain the required documents to get entry into the host country and the mechanism of issuance of the security guarantees, corruption and informal payments, and on earth comes from the lack of supporting policy frameworks as well as human and institutional capacities, which is the natural result of non-compliance with the CBTA.

\subsection{Logistics Associations}

Logistics associations are deemed to unite companies domestically and establish contacts with associations from the same industry in other countries. Also, these associations could collect information about foreign markets, including the supply-demand situation, and then spread this information among domestic producers. And most importantly, associations could act as a bridge or a lobby group between companies and the members of governments to coordinate the contradiction between practices and regulations of CBTA and bilateral agreements at this moment, when CBTA has been ratified by all members but suspended.

However, if such associations were self-centered protectionist, trade costs would be higher. There are, however, detrimental policies, like taking a stand in keeping and even increasing transshipments at the borders to protect the Lao trucking industry. This protectionist attitude comes from the perception that a liberal opening of the border with Thailand would result in a takeover of the trade transport in Lao PDR by Thai operators, which have far larger, more modern and efficient fuel vehicle fleets with lower cost than Lao operators.

\subsection{Others}

There are other reasons why the logistic performance along NSEC is unsatisfied. For instance, the incompatibilities remain between PRC standards and the rest of GMS member states in vehicle dimensions. Also, road condition is one of the factors being complained as the adverse elements in the Lao PDR, where average speeds, compared to 80-100 kilometers/hour in PRC and Thailand, however, drop to 20-60 due to mountainous terrain, winding road, and road condition's deteriorating with long and deep lane grooves. Further, someone may complain the bad performance in the Lao PDR originates from the unbalanced profits distribution in operating this corridor acting for transmission only. 
To sum up, it can be concluded that NSEC is far from being defined as its term suggested, although the physical connectivity has been completed. Along this corridor, it is the software connectivity, set forth already but suspended, that exposes it to hurdles away from the efficient connectivity.

\section{Conclusion and Recommendation}

\subsection{Conclusion}

After the conclusion, what are to be indicated are how to understanding the term ETC-efficient transport connectivity and what are required for ETC along the NSEC and then what is the implication for other corridors of GMS.

\subsubsection{Definition of ETC}

So ETC can be defined as a systematical set of hardware and software structures, facilities or infrastructures in the forms of road connection as the prerequisite in the former and non-tangibles (such as governmental cooperation agreements, unified operational regulatory and coordinate institutional frameworks, transparent governance mechanisms, and social networks) as the supporting of the hardware infrastructure, in the transport process focusing on reasonable least time and cost along a corridor within a cross-border community or sub-region for the purpose of supporting cooperative and coordinate social and economic development of sustainability to a greater sense. Also, ETC is characterized by the followings. The first prior requisite is the physical connections; the key to work relies on the software connectivity, especially in border crossings; the focus of ETC is to realize the least output in time and cost; the target pays to the social and economic development among members generating from foreign trade, for both present and future considerations.

In particular, ETC along NSEC (central part) of GMS is indicated by the hardware infrastructure (the completions of road connection from Bangkok, Thailand to Kunming, Yunnan province of PRC via Lao PDR for border crossings) and software infrastructure (such as CBTA, unified logistics operation and standards, logistics association made of main logistics companies from three members, simplified one-stop customs clearance, BEZ and sustainable financial mechanism) in the whole process of transport of goods as quick as possible along NSEC of GMS for satisfying the trade among members and thus bringing along the social and economic development of sustainability for member economies. Thus, for realization of ETC along NSEC, what are to be further required are in software connectivity-implementation of CBTA, setting-up an association of logistics enterprises, a framework for inspiring trade through E-commerce and BEZ and sustainable financing.

\subsubsection{Determinants of ETC}

As the definition of ETC explains itself, the determinants of ETC could be illustrated in the following table. As the table shows, ETC consist of the both the hardware and software connectivity in a general way. Among 9 determinants in both two aspects, only 2 factors in hardware infrastructure has been realized. We can conclude that both the governments and 
enterprises, who work collaborate and independently with diversified and identified tasks, should participate in this progress, during which the logistics associations could act at the bridge between governments and enterprises or operators in each step. Among determinants in software connectivity, BEZ and E-commerce take all three members' benefits into full and equal account, a sustainable concern for shared profits of all parties. And AIIB is the complementary financial mechanism before the realization of PPP.

Table 3: Efficient Transportation Connectivity along NSEC of GMS

\begin{tabular}{|c|c|c|c|c|c|}
\hline \multicolumn{6}{|c|}{ Efficient Transportation Connectivity } \\
\hline \multicolumn{3}{|c|}{ Hardware Infrastructure } & \multicolumn{3}{|c|}{ Software Infrastructure } \\
\hline Determinants & $\begin{array}{c}\text { Responsible } \\
\text { By }\end{array}$ & Purpose & Determinants & $\begin{array}{c}\text { Responsible } \\
\text { By }\end{array}$ & Purpose \\
\hline \multirow{2}{*}{$\begin{array}{c}\text { Physical } \\
\text { Infrastructu } \\
\text { re } \\
\text { (Finished in } \\
\text { 2013) }\end{array}$} & \multirow[t]{2}{*}{$\begin{array}{c}\text { Governmen } \\
\text { ts }\end{array}$} & \multirow[t]{2}{*}{$\begin{array}{c}\text { Completion } \\
\text { of Physical } \\
\text { Links }\end{array}$} & $\begin{array}{c}\text { Government } \\
\text { al } \\
\text { Cooperation } \\
\text { (CBTA) }\end{array}$ & Governments & $\begin{array}{l}\text { Connectivity } \\
\text { Agreements }\end{array}$ \\
\hline & & & Associations & Enterprises & $\begin{array}{l}\text { Lobby } \\
\text { Group }\end{array}$ \\
\hline \multirow{3}{*}{$\begin{array}{c}\text { Connection } \\
\text { of Missing } \\
\text { Links } \\
\text { (Finished } \\
\text { before 2013) }\end{array}$} & \multirow[t]{3}{*}{$\begin{array}{l}\text { Governmen } \\
\text { ts and/or } \\
\text { Investors }\end{array}$} & \multirow{3}{*}{$\begin{array}{l}\text { Completion } \\
\text { or } \\
\text { Improving } \\
\text { of Physical } \\
\text { Links }\end{array}$} & $\begin{array}{c}\text { One-Stop } \\
\text { BCP }\end{array}$ & $\begin{array}{l}\text { Governments } \\
\text { \& Brokers }\end{array}$ & $\begin{array}{c}\text { Smooth } \\
\text { Customs } \\
\text { Formalities }\end{array}$ \\
\hline & & & BEZ & $\begin{array}{c}\text { Governments } \\
\text { \&PPP }\end{array}$ & $\begin{array}{c}\text { Improving } \\
\text { Value of } \\
\text { Consignmen } \\
\text { ts }\end{array}$ \\
\hline & & & AIIB & Governments & Sustainable \\
\hline \multirow[t]{2}{*}{$\begin{array}{c}\text { Maintenanc } \\
\text { es }\end{array}$} & \multirow{2}{*}{$\begin{array}{c}\text { Governmen } \\
\text { ts and/or } \\
\text { PPP }\end{array}$} & \multirow{2}{*}{$\begin{array}{l}\text { Sustainable } \\
\text { Improving } \\
\text { of } \\
\text { Infrastructu } \\
\text { re }\end{array}$} & & & $\begin{array}{l}\text { Financing } \\
\text { Mechanism }\end{array}$ \\
\hline & & & $\begin{array}{c}\text { E-Commerc } \\
\mathbf{e}\end{array}$ & $\begin{array}{c}\text { Enterprises } \\
\& \\
\text { Governments }\end{array}$ & $\begin{array}{c}\text { Impetus of } \\
\text { Cross-borde } \\
\text { r Trade }\end{array}$ \\
\hline
\end{tabular}

Notes: Enterprises mainly refer to shippers, consignees and brokers

PPP: Public Private Partnership

Source: Authors.

This paper only focuses on the main sub-corridor of NSEC, the rest two western and eastern sub-corridors needed to be included for the whole understanding of NSEC. Also, the freight volume along this corridor is limited in the volume from the trade between Thailand and Yunnan province. There may some frontier trade between Lao and Thailand and between Lao and Yunnan. There still some illegal trade, which data could not be collected or verified. 


\subsection{Recommendations}

This research is to be expanded and developed in following aspects. Firstly, as a cooperation program across borders among economies with much diversity in politics, economy and social development, so the cooperation for economic concern could not be planed or implemented individually. It is worthy of noting that political consideration such as the information sharing and security are always the critical parts which are unavoidable. So, separate research is required at this field to support the possibility and degree of further cooperation. In addition, NSEC, among three corridors of GMS, is not an independent and segment infrastructure. One one hand, for the central sub-corridor studied in this research, the section what has been discussed is set from Kunming, Yunnan province, PRC (the origin) to Bangkok, Thailand (the destination). In real practice, it is impossible to cut the corridor off to a segment or limited distance. So further research should pay attention to where the central sub-corridor stretches at Kunming and Bangkok, which may imply bigger markets for both Thailand and Yunnan. On the other hand, among three corridors of GMS, they are not separately elongated, but intersected at some points. So, this research should be extended to the coordination of ETC in the whole GMS and later in the AEC and in ASEAN. Besides, another study should focus on the complementary and competitiveness accordingly for the sustainable industrial upgrade. Further, since the trilateral agreement between Thailand, Lao PDR, and PRC has not yet been enacted, all cargo will continue to be transshipped at the border. This regulatory barrier offers the opportunity for Lao PDR to provide value-added services to the fruit trade such as sorting, grading, packaging, etc. However, further research is needed to investigate the willingness of consumers to pay for better quality products by using refrigerated containers along the whole process of cold-chain. And lastly, how PPP could help finance the regional project and work with AIIB should be studied specifically. 


\section{References}

i. ADB and ADBI,, 2013. Connecting South Asia and Southeast Asia, Interim Report, A Joint Study of the Asian Development Bank and the Asian Development Bank Institute.. [Online] Available at: www.adb.org

ii. ADB and ADBI, 2009. Infrastructure Seamless Asia, A Joint Study of the Asian Development Bank and the Asian Development Bank Institute. [Online]

Available at: www.adb.org.

iii. ADBI, 2014. Asian Development Bank Institute, Connecting Central Asia with Economic centers. [Online] Available at: www.adb.org.

iv. Alama'-Sabater, L., Ma'rquez-Ramos, L. \& Sua'rez-Burguet, C., 2013. Trade and transport connectivity: a spatial approach. Applied Economics , Volume 45, pp. 2563-2566.

v. Chirathivat, S. \& Cheewatrakoolpong, K., 2015. Thailand's Economic Integration with Neighboring Countries and Possible Connectivity with South Asia, ADBI Working paper Series. [Online]

Available at: http://www.adbi.org/working-paper/2015/04/03/6589.thailand.economic.integration

vi. De, P., 2014. Economic Corridors and Regional Economic Integration. Developing Economic Corridors in South Asia , s.l.: ADB.

vii. Florento, H. \& Corpuz, M. I., 2014. Myanmar: The Key Link between South Asia and Southeast Asia, Asian Development Bank Institute.. [Online]

Available at: www.adb.org.

viii. Jian-you, Z. et al., 2012. Predictive method of highway freight volume based on fuzzy linear regression model.. Journal of Traffic and Transportation Engineering, 12(3).

ix. Moe Thuzar, R. M., Hutchinson, F., Than, T. M. M. \& Chalermpalanupap, T., 2014. Connecting South and Southeast Asia: Implementation Challenges and Coordination Arrangements, ADBI Working Paper Series.. [Online] Available at: www.adb.org

x. Neogi, C., 2014. Infrastructure Development, Industrial Agglomeration and Regional Trade in South Asia. Developing Economic Corridors in South Asia. s.l.:ADB.

xi. Rahmatullah, M., 2009. Regional Connectivity: Opportunities for Bangladesh to be a Transport Hub. Journal of Bangladesh Institute of Planners, Volume 2, pp. 13-29. 
xii. Raychaudhuri, A. \& De, P., 2014. Economic Corridors, Trade Costs, and regional Production Networks in South Asia. Developing Economic Corridors in South Asia, s.l.: ADB.

xiii. Sen, K., 2014. Global Production Networks and Economic Corridors: Can They be Drivers for South Asia's Growth and Regional Integration? ADB Working Serious Paper. [Online] Available at: www.adb.org.

xiv. Shi, C., 2008. The Research of Forecast Method and Application of Cargo.. s.l.:Wuhan University of Technology .

xv. Xia, Y., Panichakarn, B. \& Bunditkul, S., 2015. Freight Forecasting along North South Economic Corridor Based on Fuzzy Linear Regression. Proceedings of the 4th Asia Pacific Conference on Advanced Research. s.l., Asia Pacific Conference on Advanced Research. 